\title{
EVALUASI KUALITATIF PENGGUNAAN ANTIBIOTIK CEFTRIAXONE PADA PASIEN DEMAM TYFOID ANAK RUANGAN RAWAT INAP RSUD DELI SERDANG
}

\author{
Yayuk Suyudi Rahayu ${ }^{1}$, Suci Wulandari ${ }^{2}$, Titi Anjar Pangestuti ${ }^{3}$ \\ Institut Kesehatan Medistra Lubuk Pakam. \\ e-mail : rahayuyayuksuyudi@gmail.com \\ DOI $10.35451 /$ jfm.v3i2.567
}

\begin{abstract}
Typhoid fever is a systemic infection caused by the salmonella thypi bacteria which attacks the small intestine with fever for 1 week or more accompanied by disturbances in the digestive tract. This disease is endemic and is a community disease that is transmitted through food and drink contaminated with bacteria. Typhoid fever can be treated using antibiotics, giving antibiotics especially in children and infants must consider the side effects on body systems and organ function that are still not perfect. The purpose of this study was to determine the use of ceftriaxone antibiotics based on the right indication, appropriate patient, appropriate medication, proper dosage, timely administration of the drug and the right way of giving antibiotics in the inpatient installation of the Deli Serdang Regional General Hospital in 2019.

This study used retrospective data and was analyzed descriptively by purposive sampling method. Data used by pediatric patients (2-12 years). Data according to the inclusion characteristics of 43 cases were evaluated for their quality based on the right indication, appropriate patient, appropriate medication, proper dosage, the right time of administration and the right way of administration.

The results of this study indicate that the percentage of the quality of antibiotic use includes $43(100 \%)$ right indications, $43(100 \%)$ right patients, $43(100 \%)$ right drugs, 30 (73\%) right doses, 42 right time of administration ( $97.67 \%)$ and the right way of giving was 43 (100\%).
\end{abstract}

Keywords: Quality of Antibiotic Use, Child Typhoid Fever, Ceftriaxone.

\section{PENDAhUluan}

Negara Indonesia termasuk kedalam sepuluh besar dengan angka kejadian penyakit infeksi yang tinggi, sehingga penggunaan terapi antibiotik cukup tinggi. Semakin banyaknya penggunaan antibiotik dapat menyebabkan peningkatan efek samping antibiotik irrasional. Penggunaan antibiotik yang tidak rasional yaitu penggunaan tanpa resep dokter. Data WHO menunjukkan bahwa sebnayak 64\% negara di Asia Tenggara menggunakan antibiotik tanpa resep. Penelitian tim pada dua rumah sakit pendidikan yang ada di indonesia mendapatkan hanya $21 \%$ peresepan antibiotik yang tergolong 
rasional. Penggunaan antibiotik irrasional dapat meningkatkan angka resistensi terhadap antibiotik (Nurhanif, 2020).

Kasus demam tifoid rentan terjadi pada anak-anak. Di indonesia sendiri, kasus demam tifoid paling banyak terjadi pada anak usia 3-19 tahun, meskipun gejala yang dirasakan pasien anak cenderung tidak khas. Demam tifoid adalah suatu penyakit endemis yang biasa disebabkan oleh Salmonella typhosa juga menginfeksi saluran pencernaan sehingga mengakibatkan peradangan pada bagian usus halus dan lumen usus (Oswari, 2015).

Antibiotik yang dikategorikan sebagai bakteriostatik merupakan jenis antibiotika yang bekerja dengan mencegah atau menghambat pertumbuhan kuman (Rahmawati, 2019).

Ceftriaxone adalah salah satu contoh antibiotik golongan beta-lactamase bekerja pada spektrum luas, memiliki waktu paruh yang panjang sehingga dapat diberikan 1-2 kali sehari. Lama demam turun rata-rata empat hari, biasanya hasil uji bakteri semua biakan akan menjadi negatif pada hari keempat, dan tidak ditemukan kekambuhan. Hasil laboratorium menunjukkan kadar hemoglobin dan hitung leukosit normal, serta tidak ditemukan angguan fungsi hati dan ginjal (Sidabutar,2010).

\section{METODE}

Jenis penelitian yang dilakukan yaitu penelitian non-eksperimental cross sectional yang bersifat observasional.

a. Tempat penelitian

Lokasi Penelitian ini akan dilakukan dibagian rekam medik di Rumah Sakit Umum Daerah Deli Serdang.

b. Populasi dan Sampel
Populasi penelitian ini adalah seluruh data rekam medik pasien anak typoid paa periode Januari s/d Desember 2019 sebanyak 105 rekam medik di Rumah Sakit Umum Daerah Deli Serdang tahun 2019.

c. Tekhnik Pengambilan Sampel

Teknik sampling yang digunakan teknik pengambilan data secara purposine dengan tidak membandingkan dengan sampel lain. Untuk membatasi kriteria sampel dari pasien maka dilakukan kriteria yaitu inklusi daan eksklusi.

- Kriteria inklusi yaitu pasien yang menggunakan antibiotic ceftriaxone dan pasien demam tipoid yang berusia 2-12 tahun.

- Kriteria ekslusi yaitu pasien didiagnosa tipoid dengan komplikasi penyakit lain dan pasien bisa tidak terselamatkan.

d. Pengumpulan Data

Penelusuran data pasien demam tifoid Rumah Sakit Umum Daerah Deli Serdang pada periode Maret-Mei 2020. Dengan data yang diambil yaitu (nama, jenis kelamin, usia, berat badan, tanggal perawatan dan data obat yang dikonsumsi). Pengolahan data dilakukan dengan cara evaluasi penggunaan antibiotik yang digunakan pada pasien meliputi tepat dosis, tepat indikasi, tepat pasien, tepat obat, tepat rute pemberian dan lama pemberian.

\section{HASIL DAN PEMBAHASAN}

Dari data rekam medik pasien anak di rumah sakit umum daerah deli serdang lubuk pakam. Pada bulan januari- desember 2019 terdapat 105 pasien anak yang terdiagnosa demam tifoid.

1. Pasien tipoid anak

Penelitian yang telah dilakukan mendapatkan hasil bahwa pasien anak demam tifoid rawat inap di Rumah Sakit 
Umum Daerah Deli Serdang tahun 2019 yang dapat dilihat pada table 1.

Tabel 1. karakteristik pasien demam typoid pada bulan januari-desember 2019.

\begin{tabular}{lll}
\hline Jenis kelamin & $\mathrm{N}$ & $\begin{array}{l}\text { Persentase } \\
(\%)\end{array}$ \\
\hline Laki- laki & 24 & 55,81 \\
\hline Perempuan & 19 & 44,19 \\
\hline Total & 43 & 100
\end{tabular}

Tabel di atas menunjukkan bahwa dari 43 pasien anak demam tifoid yang diambil secara retrospektif terlihat jenis kelamin yang paling banyak adalah lakilaki $(55,81 \%)$ dan selebihnya adalah perempuan $(44,19 \%)$.

\section{Berdasarkan Usia Pasien}

Pasien demam tifoid berdasarkan usia di Rumah Sakit Umum Daerah Deli Serdang Pada tahun 2019 dapat dilihat pada table 2 .

Tabel 2 Karakteristik pasien anak demam tifoid berdasarkan umur pakam pada bulan januari-desember 2019 .

\begin{tabular}{lll}
\hline $\begin{array}{l}\text { Usia } \\
\text { pasien }\end{array}$ & $\mathrm{N}$ & $\begin{array}{l}\text { Persentase } \\
(\%)\end{array}$ \\
\hline 2-6 tahun & 22 & 51,16 \\
\hline $\begin{array}{l}\text { 7-12 } \\
\text { tahun }\end{array}$ & 21 & 48,84 \\
\hline Total & 43 & 100
\end{tabular}

Tabel di atas menunjukkan bahwa dari 43 pasien anak demam tifoid yang paling banyak terjadi rentang usia 2- 6 tahun sebesar 22 pasien $(51,16 \%)$.

3. Rata-rata Pasien Rawat Inap

Rata-rata rawat inap pasien anak demam tifoid yang ada di Rumah Sakit Umum Daerah Deli Serdang tahun 2019. Indikator ini digunakan untuk meningkatkan pelayanan di Rumah Sakit.
Tabel 3. Karakteristik pasien demam typoid di Rumah Sakit Umum Daerah Deli Serdang tahun 2019 berdasarkan lama rawat inap.

\begin{tabular}{ccc}
\hline $\begin{array}{c}\text { Lama } \\
\text { rawat } \\
\text { inap } \\
\text { (hari) }\end{array}$ & $\mathrm{N}$ & Persentase $(\%)$ \\
\hline 3 & 1 & 2,32 \\
\hline 4 & 8 & 18,60 \\
\hline 5 & 22 & 51,17 \\
\hline 6 & 10 & 23,26 \\
\hline 7 & 1 & 2,32 \\
\hline 12 & 1 & 2,32 \\
\hline Total & 43 & 100 \\
\hline
\end{tabular}

Hasil dari tabel 3 menunjukkan adanya lama rawat inaplebih dari 1 minggu hal ini memungkinkan disebabkan karena faktor dari beratnya penyakit yang dialami pasien yang membuat pasien lama dirawat dirumah sakit, pada perawatan demam tifoid normalnya yaitu 1-10 hari tetaapi pada tabel didapatkan hasil paling banyak yaitu perawatan selama 5 hari sebanyak 22 pasien $(51,17 \%)$ dengan kondisi membaik.

\section{Ketepatan Obat}

Ketepatan obat disesuaikan dengan panduan praktik klinik dari kepmenkes 2014 dan formularium Rumah Sakit yang diberikan kepada pasien dapat dilihat pada tabel 4 .

Tabel 4. ketepatan obat pada pasien anak demam tifoid di RSUD Deli Serdang tahun 2019

\begin{tabular}{|c|c|c|c|c|}
\hline \multirow[t]{2}{*}{ Antibiotik } & \multirow[t]{2}{*}{$\begin{array}{l}\text { Rut } \\
\mathrm{e}\end{array}$} & \multirow[t]{2}{*}{$\begin{array}{l}\text { Jumla } \\
\text { h } \\
\text { pasie } \\
\text { n }\end{array}$} & \multicolumn{2}{|c|}{$\begin{array}{c}\text { Ketepatan } \\
\text { Obat } \\
\text { Menurut } \\
\text { Kepmenkes } \\
2014\end{array}$} \\
\hline & & & $\begin{array}{l}\text { Tida } \\
\mathrm{k} \\
\text { tepa } \\
\mathrm{t}\end{array}$ & $\begin{array}{l}\text { Tep } \\
\text { at }\end{array}$ \\
\hline $\begin{array}{l}\text { Ceftriaxo } \\
\text { ne }\end{array}$ & IV & 43 & & 43 \\
\hline Jumlah & & & & 43 \\
\hline
\end{tabular}




\begin{tabular}{ll}
\hline Persentas & 100 \\
e $(\%)$ & $\%$ \\
\hline
\end{tabular}

Berdasarkan tabel diatas dapat dilihat pemberian pengobatan antibiotik pada pasien anak demam tifoid baik berupa pengobatan tunggal maupun pengobatan kombinasi yang sudah didapat kemudian disesuaikan dengan panduan praktik klinik dan formularium rumah sakit didapatkan hasil kesesuaian pengobatan $(100 \%)$ tepat obat sebanyak 43 pasien.

5. Ketepatan Dosis

Ketepatan dosis dilihat dari besaran dosis yang diberikan, frekuensi pemberian antibiotik, dan durasi pemberian antibiotik tersebut dapat dilihat pada table 5 .

Tabel 5. Ketepatan dosis pada pasien anak demam tifoid di instalasi rawat inap RSUD Deli Serdang

\begin{tabular}{|c|c|c|c|c|}
\hline \multirow{2}{*}{$\begin{array}{l}\text { Lama } \\
\text { Penggunaa } \\
\text { n Antibiotik } \\
\text { Standar } \\
\text { Kepmenkes } \\
2014\end{array}$} & \multirow{2}{*}{$\begin{array}{l}\text { Dosis } \\
\text { Pema } \\
\text { kaian }\end{array}$} & \multirow[t]{2}{*}{$\mathrm{N}$} & \multicolumn{2}{|c|}{$\begin{array}{l}\text { Ketepa } \\
\text { tan }\end{array}$} \\
\hline & & & $\begin{array}{l}\text { Tid } \\
\text { ak } \\
\text { Te } \\
\text { pat }\end{array}$ & $\begin{array}{l}\mathrm{T} \\
\mathrm{e} \\
\mathrm{p} \\
\text { at }\end{array}$ \\
\hline $\begin{array}{l}\text { Ceftriaxone } \\
: \quad \text { Dosis }\end{array}$ & $\begin{array}{l}1 \times 800 \\
\mathrm{mg}\end{array}$ & 1 & & 5 \\
\hline & $\begin{array}{l}1 \times 100 \\
0 \mathrm{mg}\end{array}$ & 2 & & $\begin{array}{l}1 \\
2\end{array}$ \\
\hline $\begin{array}{l}\text { gram/hari) } \\
\text { selama 2- }\end{array}$ & $\begin{array}{l}2 \times 500 \\
\mathrm{mg}\end{array}$ & 9 & & $\begin{array}{l}2 \\
1\end{array}$ \\
\hline $5 n$ hari & $\begin{array}{l}2 \times 100 \\
0 \mathrm{mg}\end{array}$ & 9 & & 4 \\
\hline & $\begin{array}{l}2 \times 750 \\
\mathrm{mg}\end{array}$ & 6 & 1 & \\
\hline Jumlah & & $\begin{array}{l}4 \\
3\end{array}$ & 1 & $\begin{array}{l}4 \\
2\end{array}$ \\
\hline $\begin{array}{l}\text { Persentase } \\
(\%)\end{array}$ & & & $\begin{array}{l}2,2 \\
3\end{array}$ & $\begin{array}{l}9 \\
7 . \\
6 \\
7\end{array}$ \\
\hline
\end{tabular}

Berdasarkan hasil data pada tabel 4.5 menunjukan bahwa kasus yang menyatakan tepat dosis sebanyak 31 kasus (73\%) dan 12 kasus (27\%) menunjukkan ketidaksesuaian dosis.

6. Lama Penggunaan Antibiotik
Lama penggunaan antibiotik harus disesuaikan dengan keadaan pasien agar tidak terjadi resistensi pada antibiotik yang dapat dilihat pada tabel 6.

Tabel 6. Ketepatan lama penggunaan antibiotik ceftriaxone pada pasien anak demam tifoid di Rumah Sakit.

\begin{tabular}{|c|c|c|c|c|}
\hline \multirow{2}{*}{$\begin{array}{l}\text { Lama } \\
\text { Pengguna } \\
\text { an } \\
\text { Antibiotik } \\
\text { Standar } \\
\text { Kepmenk } \\
\text { es } 2014\end{array}$} & \multirow[b]{2}{*}{$\begin{array}{l}\text { Lam } \\
\text { a } \\
\text { Peng } \\
\text { gun } \\
\text { aan }\end{array}$} & \multirow[t]{2}{*}{$\mathrm{N}$} & \multicolumn{2}{|c|}{$\begin{array}{l}\text { Ketepata } \\
\mathrm{n}\end{array}$} \\
\hline & & & $\begin{array}{l}\text { Tid } \\
\text { ak } \\
\text { Te } \\
\text { pat }\end{array}$ & $\begin{array}{l}\text { Te } \\
\text { pa } \\
\text { t }\end{array}$ \\
\hline $\begin{array}{l}\text { Ceftriaxon } \\
\mathrm{e}: \text { Dosis }\end{array}$ & $\begin{array}{l}3 \\
\text { hari }\end{array}$ & 5 & & 5 \\
\hline & $\begin{array}{l}4 \\
\text { hari }\end{array}$ & 12 & & 12 \\
\hline & $\begin{array}{l}5 \\
\text { hari }\end{array}$ & 21 & & 21 \\
\hline $\begin{array}{l}\text { selama } \\
\text { 2-5n hari }\end{array}$ & $\begin{array}{l}6 \\
\text { hari }\end{array}$ & 4 & & 4 \\
\hline & $\begin{array}{l}9 \\
\text { hari }\end{array}$ & 1 & 1 & \\
\hline Jumlah & & 43 & 1 & 42 \\
\hline $\begin{array}{l}\text { Persentas } \\
\text { e }(\%)\end{array}$ & & & $\begin{array}{l}2,2 \\
3\end{array}$ & $\begin{array}{l}97 . \\
67\end{array}$ \\
\hline
\end{tabular}

Berdasarkan data dari tabel 6 didapatkan hasil 42 kasus $(97,67 \%)$ sesuai dengan lama penggunaan antibiotik dan 1 kasus $(2,23 \%)$ tidak sesuai dengan penggunaan antibiotik yang seharusnya.

7. Tepat Pemberian

ketepatan cara pemberian antibiotik yang sesuai dengan kondisi pasien serta sesuai dengan sediaan yang ada pada antibiotiknya dapat dilihat pada table 7 .

Tabel 7 Ketepatan Pemberian Obat

\begin{tabular}{llcc}
\hline Antibiotik & Cara & \multicolumn{2}{c}{ Ketepatan } \\
\cline { 3 - 3 } & $\begin{array}{l}\text { pemb } \\
\text { erian }\end{array}$ & $\begin{array}{l}\text { Tidak } \\
\text { tepat }\end{array}$ & Tepat \\
\hline Ceftriaxone & IV & 43 \\
\hline Jumlah & & 43 \\
\hline $\begin{array}{l}\text { Persentase } \\
\text { (\%) }\end{array}$ & & 100
\end{tabular}

(\%)

Berdasarkan tabel 1.7 dapat dilihat cara pemberian antibiotik yang tepat adalah 43 pasien $(100 \%)$. Dalam penelitian ini cara pemberian antibiotik ceftriaxone sudah tepat. 


\section{KESIMPULAN}

Setelah di evaluasi penggunaan antibiotik pada pasien anak demam tifoid di Rumah Sakit Umum Daerah Deli Serdang berdasarkan standart pelayanan medik di Rumah Sakit Umum Daerah Deli Serdang tentan diagnosa demam tifod dengan meliputi 6 aspek yaitu tepat indikasi tepat pasien, tepat obat, tepat dosis, tepat lama pemberian dan tepat cara pemberian. Dari hasil penelitian pada 43 pasien anak demam tifoid yang menjalani rawat inap di Rumah Sakit Umum Daerah Deli Serdang pada tahun 2019 yang di dapatkan nilai persentase untuk tepat indikasi sebanyak $43(100 \%)$, tepat pasien sebanyak $43(100 \%)$, tepat obat sebanyak $43(100 \%)$, tepat dosis sebanyak 31 (73\%), tepat lama pemberian sebanyak $42(97,67)$, dan tepat cara pemberian sebanyak 43 $(100 \%)$.

\section{DAFTAR PUSTAKA}

Arikunto, Suharsimi., 2010. Prosedur Penelitian. Yogyakarta: Rineka Cipta.

Bernadi, W, Nurul M., 2015. Evaluasi Penggunaan Antibiotik Pada Pasien Anak Demam Tifoid di Instalasi Rawat Inap RSUD $\mathrm{dr}$. Sayidiman Magetan Tahun 2014. Skripsi. Surakarta: Fakultas Farmasi Universitas Muhammadiyah Surakarta.

Depkes., 2006. Modal Pelatihan Penggunaan Obat Rasional. Jakarta : Departemen Kesehatan RI.

Florensia, A., 2016. Evaluasi Penggunaan Obat Antihipertensi di Instalasi Rawat Inap RSUD Kota Tanggerang dengan Metode Anatomical Therapeutic chemical/Defined Daily Dose pada Tahun 2015. Skripsi. Jakarta: Program Studi Farmasi.
Ika Sutra Perwirahayu Saputri., 2016. Evaluasi Penggunaan Antibiotik Pada Pasien Demam Tifoid Anak di Instalasi Rawat Inap RSAU Adi Soemarmo. Surakarta: Fakultas Farmasi Universitas Muhammadiyah Surakarta.

Ivan Elsbeth Purba,dkk., 2016. Program Pengendalian Demam Tifoid: Tantangan dan Peluang. Medan: Universitas Sari Mutiara Indonesia.

Kementerian Kesehatan Republik Indonesia., 2011. Pedoman Penggunaan Antibiotik. Jakarta: Kemenkes RI.

Keputusan Kesehatan Republik Indonesia. Nomor 364/MENKES/SK/V/2006. Tentang Pengendalian Demam Tifoid.

Made Agus Hendrayana.,dkk.,2017. Identifikasi dan Diagnosis Infeksi Bakteri Salmonella typhi. Denpasar: Fakultas Kedokteran Universitas Udayana.

Maryunani, Anik., 2018. Ilmu Kesehatan Anak Dalam Kebidanan. Jakarta: TIM.

Nelwan R.H.H., 2012. Tata Laksana Terkini Demam Tifoid, Continuing Medical Education, CDK-192/Vol.39, no 4, halaman 248-249.

Muhammad Nurhanif dan Insan Sosiawan.A Tunru., 2020. The Differences of Antibiotik Effectiveness in Therapy of Thypoid Fever without Complications In Children at Putra Bahagia Hospital Cirebon. Jakarta: Fakultas Kedokteran Universitas Yarsi.

Nursalam, dkk., 2018. Asuhan Keperawatan Bayi dan Anak. Jakarta: Salemba Medika.

Oswari, E., 2015. Penyakit dan Penanggulangannya. Jakarta: Balai Penerbit FKUI.

Peraturan Menteri Kesehatan Republik Indonesia., 2016. Standar Pelayanan Kefarmasian Dirumah 
Sakit. Jakarta: Permenkes RI. Halaman 58-63.

Peraturan Menteri Kesehatan Republik Indonesia, 2011. Pedoman Umum Penggunaan Antibiotik. Jakarta: Kementerian Kesehatan RI, 874.

Puspita, Angelina., 2012. Profil Pemberian Antibiotika Rasional pada Pasien Demam Tifoid Anak di Bangsal Rawat Inap RSUD Tanerang Tahun 2010-2011, hal 4-11. Skripsi . Jakarta: Fakultas Farmasi UIN Syarif Hidayatullah.

Radji, Maksum., 2018. Antibiotik dan Kemoterapi. Jakarta: Penerbit Buku Kedokteran EGC.

Riyadi. S dan Suharsono., 2019. Asuhan Keperawatan pada Anak Sakit. Yogyakarta: Gosyen Publishing.

Sevilla, Consuelo G. Et. Al., 2007. Research Methods. Rex Printing Company: Quezon City.

Shimond Purba, dkk., 2017. Gambaran Penderita Demam Tifoid Pada Remaja Awal yang Dirawat Inap di Rumah Sakit Umum Daerah Deli Serdang Lubuk Pakam Tahun 2016. Medan: Fakultas Kedokteran Universitas Methodist Indonesia.

Sidabutar.,S., Satari,H.I., 2010. Pilihan Terapi Empiris pada Anak: Kloramfenikol atau seftriakson?. Sari Pediatri. 11, 439-9.

Soedarmo, Sumarno S.P.,dkk., 2012. Demam Tifoid, Dalam: Buku Ajar Infeksi Pediatri Tropis. Jakarta: Ikatan Dokter Indonesia. Hal 338-345.

Sugiyono., 2015. Metode Penelitian Pendidikan (Pendekatan Kuantitatif, Kualitatif dan R\&O). Bandung: Penerbit CV.Alfabeta.

Swestika, Swandri., 2012. Penggunaan Obat Rasional Melalui Indikator 8 Tepat dan 1 Waspada. Makasar: Balai Pustaka Pelatihan Kesehatan.

Rouli Meparia Utami, 2017. Identifikasi Drug Related Problem(DRPs) pada pasien Pasien Demam Tifoid Anak di Instalasi Rawat Inap Rumah Sakit " $x$ "
Tanggerang Selatan. Jakarta: Fakultas Kedokteran Universitas Islam Negeri Syarif Hidaytullah. 